\title{
Juvenile hyaline fibromatosis
}

INSERM

\section{Source}

INSERM. (1999). Orphanet: an online rare disease and orphan drug data base. Juvenile hyaline fibromatosis. ORPHA:2028

Juvenile hyaline fibromatosis (JHF) is a rare bone dysplasia, characterized by papulonodular skin lesions (especially around the head and neck), soft tissue masses, gingival hypertrophy, joint contractures, and osteolytic bone lesions in variable degrees. Joint contractures may cripple patients and delay normal motor development if occuring in infancy. Severe ging ival hyperplasia can interfere with eating and delay dentition. Histopathology analysis of involved tissues reveals cords of spindle-shaped cells embedded in an amorphous, hyaline material. JHF is a mild form of infantile systemic hyalinosis (see this term). 